\title{
A COMPARATIVE STUDY ON APPLE CHLOROTIC LEAFSPOT VIRUS (ACLSV) ISOLATES FROM DIFFERENT HOSTS IN THE EAST MEDITERRANEAN REGION OF TURKEY
}

\author{
KOÇ, G. ${ }^{1 *}-$ FIDAN, $\mathrm{H}^{2}{ }^{2}-$ SARI, N. ${ }^{2}-$ ÇALIŞ, O. ${ }^{2}$ \\ ${ }^{1}$ Biotechnology Research and Application Centre, Cukurova University, Adana, Turkey \\ ${ }^{2}$ Plant Protection Dept., Akdeniz University, Antalya, Turkey \\ *Corresponding author \\ e-mail: gkmnkoc@hotmail.com
}

(Received 19 $9^{\text {th }}$ Jul 2019; accepted $15^{\text {th }}$ Nov 2019)

\begin{abstract}
The study was conducted on ACLSV (Apple Chlorotic Leafspot Virus) isolates found in samples collected from temperate zone fruit orchards in Adana and Mersin provinces and districts in the Eastern Mediterranean region of Turkey. Reported as a natural host, Styrax officinalis bush was included in the study as a different host isolate (Kayseri). Leaf and cortical samples have been tested with commercial ELISA kits for the presence of common viruses. In order to verify DAS-ELISA results, the total RNAs were used in RT-PCR test and only positive responses were obtained from ACLSV-specific antiserum and primers. ACLSV isolates obtained from different hosts in the Eastern Mediterranean region were subjected to molecular variation analyses. Possible recombination sites of ACLSV were identified in the partial sequences of coat protein genes via comparison of ACLSV sequences from the GenBank database. As a result, for the first time recombinat or variant ACLSV isolates were reported in the region. Coat Protein Nucleotide sequences based on phylogenetic trees showed that these isolates were grouped and conserved signatures of type B6 clusters. This paper confirmed that Styrax officinalis as a natural ACLSV reservoir.
\end{abstract}

Keywords: ACLSV, Rosacea and wild hosts, genetic variability, CP, East Mediterranean region of Turkey,

\section{Introduction}

ACLSV, found in the morphological subgroup A in the trichovirus group of family Betaflexiviridae, is a member of the stone and pome fruit infecting virus species leading to significant losses (Dunez, 1988; Martelli et al., 1994). ACLSV is known to have a convoluted filamentous particle of 600-740 $\times 12 \mathrm{~nm}$, and the RNA of the virus is known to be single-helical and one-part (Lister, 1970; German et al., 1990). Many strains of ACLSV are reported to have changed due to a high proportion of virus strains in their emerging symptoms; many of the strains are able to infect all hosts, but some Apple strains are difficult to transmit to stone fruits (Chairez and Lister, 1973; Smith et al., 1998; Brunt et al., 1996). ACLSV's hosts are found all over the world where they are grown and the virus is often carried without symptoms in pome fruit trees, while stonecore fruit trees suffer from very serious diseases (Nemeth, 1986; Poul and Dunez, 1988; Smith et al., 1998; Brunt et al., 1996). ACLSV, in cherry and sour cherry, are also found as latent in many varieties (Dosba et al., 1986; Desvignes and Boye, 1989). Martelli et al. (1994) thought that ACLSV was one of the most economically dangerous viruses and ACLSV is transmitted by mechanically and grafting. Flegg and Clark (1979) noted that ELISA (Enzyme Linked Immuno Sorbent Assay) is a very convenient method for diagnosing viruses in broad indexing programs and epidemiological studies, and that the classical DAS (Double Antibody Sandwich)-ELISA method can identify ACLSV from time to time, and they have developed a different procedure. Barba and Clark (1986) 
stated that the virus dispersed irregularly in trees, in a way that the leaves at the bottom of the tree contained more viruses, and that bark tissues were the most suitable material for ELISA, especially towards the end of the vegetation period. However, because of the low concentration problem of the virus is known to infect plants even with ELISA negative results.

Candresse et al. (1995) reported variability in nucleotide sequences between different isolates despite being of the same plant origin. In addition, Niu et al. (2012) underlined that ACLSV genomes are relatively variable. They analyzed ten complete genome sequences from different hosts and reported a variation percentage between 67.2 and 95.1\%. Moreover, Kuzmitskaya et al. (2016) when they compared ACLSV isolates in Belarus, Apple interpreted divergence levels of chlorotic leaf spot virus that varied in different genomic regions.

The presence of ACLSV in stone fruit trees grown in Turkey was first identified in Yalova by Yürektürk (1984) with biological indexing using GF305 peach rootstocks. The agent has been reported by different researchers in stone and pome fruits of different species, varieties and geographical origin (Dunez, 1986; Çağlayan and Çalı, 1994; Elibüyük, 1998; Fidan and Özdemir, 1998; Sipahioğlu et al., 1999; Ulubaş and Ertunç, 2004; Ulubas Serce and Rosner, 2006; Koç and Bakoglu, 2007; Koç et al., 2008; Öztürk, 2012; Değirmenci and Akbaş, 2013). But the background about the genetic variability of Apple Chlorotic Leaf Spot Virus in the East Mediterranean region and Turkey, still has influence. Therefore, we have investigated molecular variability of ACLSV isolates in Pome and Stone fruit orchard isolates from the East Mediterranean Region of Turkey (EMT) to forecast genetic relationships by analysing the nucleotide sequences of ACLSV genome via BootScan and Sisscan pro.

\section{Materials and methods}

\section{Sources of ACLSV isolates}

Temperate zone fruit orchards in the East Mediterranean region of Turkey (EMT) is generally maintained between low and high altitude $(50$ to $1360 \mathrm{~m})$ in two different condition levels. Five ACLSV isolates from samples of different plant species have been collected from commercial gardens in the area to establish genbank accession numbers.

The isolates compared in the study were selected according to host type and geographical differences and distances. In addition, these isolates originated from the samples that have been collected and tested by the same investigator team during the surveys conducted in the region in the last fifteen years. The studied isolates represent 379 samples collected from the surveys followed in the region between 2005 and 2019 (Fig. 1).

Therefore, five isolates were stepped forward as representative for the virus comparison and the region. A nectarine isolate of ACLSV was collected from Yenice/Adana (2019) and an apple isolate from Findıkl1/Adana (2011), a pear isolate from Kamışl1/Adana (2006), a sweet cherry isolate from Çamardı/Nigde (2013) and an Strax officinalis isolate supplied from Kayseri (by Dr. H. Fidan; 2018), Fresh shoots of systemically infected isolates were used as samples within nucleic acid extraction and RT-PCR assays. Collected plantlets were stored at $4{ }^{\circ} \mathrm{C}$ before when DAS-ELISA tests and nucleic acid extractions were run. All positive samples were eradicated according to national interests, internal quarantine rules and sanctions. Studies were only carried out on isolated nucleic acids. 


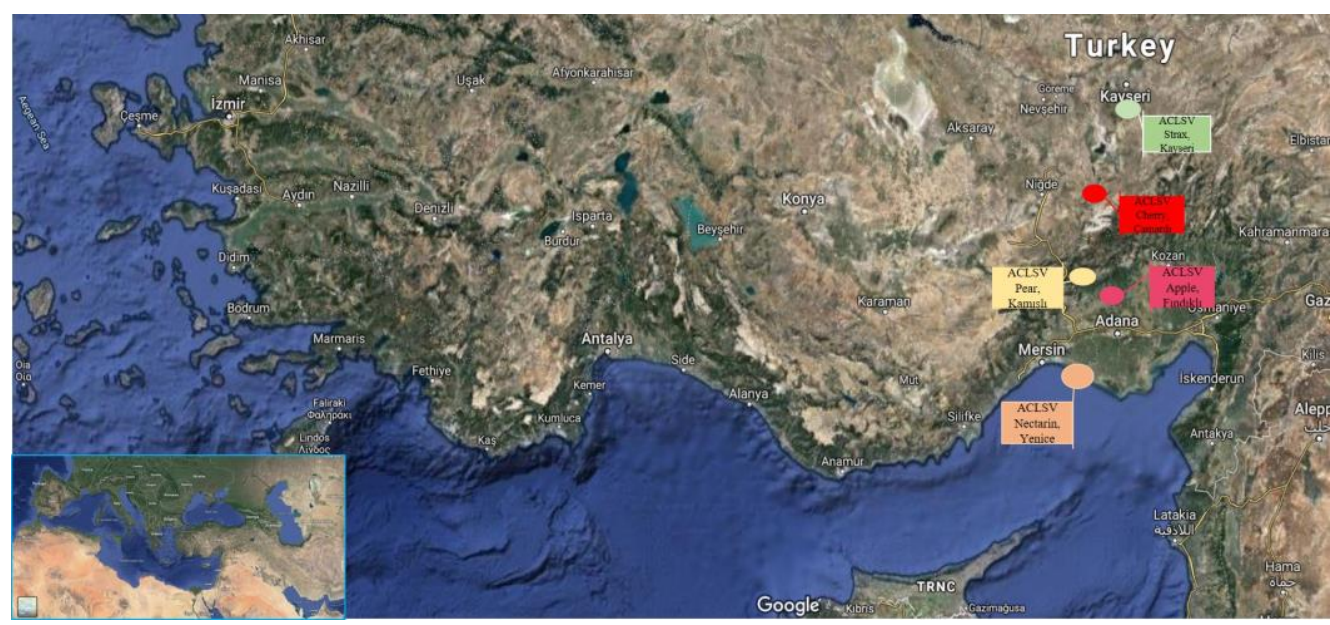

Figure 1. Isolate sources and locations of ACLSV in the East Mediterranean region of Turkey. (https://www.google.com/maps/@37.5034496,33.2747851,395256m/data=!3m1!1e3)

\section{Serological tests}

The plantlets were labelled and placed in isolated transparent bags, which were put in ice pail and transported to the virology laboratory and maintained at $4{ }^{\circ} \mathrm{C}$. All samples were tested within a day.

\section{Enzyme linked immunosorbent assay (ELISA)}

To distinguish their infection in the specimens, the leaves were tested through ELISA using polyclonal antiserum against various virus species that could possibly be found in temperate zone plants given in Table 1. Antiserums provided by Agdia (USA) and Bioreba AG, (Switzerland) were diluted in accordance with suppliers' instructions and tested according to Clark and Adams (1977). PNRSV, PDV, PPV and other possible mixed infections common in Pome and Prunus were tested by ELISA with virusspecific antibodies.

Results were made by photometric measurement of absorption values at $405 \mathrm{~nm}$ wavelength and yellow color formation in ELISA reader. At photometric absorbance values read at a wavelength of $405 \mathrm{~nm}$, samples that yielded at least twice the healthy control value and a higher reading value were considered positive or contaminated.

\section{Nucleic acid based assays, total RNA extraction and RT-PCR}

Samples with serologically positive results with ACLSV specific antibodies (Bioreba) were concentrated in molecular studies. Moreover, Nucleic acid isolations, RT-PCR and sequence analyses were performed to detect possible recombinations or variations of ACLSV isolates from the East Mediterranean in Turkey (EMT). In Molecular Studies, a pair of primers specific to the conserved regions containing some or all of the CP genes belonging to ACLSV, and identified as a result of DAS-ELISA and RT-PCR, were used.

Total nucleic acid extraction (NAE) and reverse transcription polymerase chain reaction $(R T-P C R)$

Extracted Nucleic Acid (NA) from infected plants were processed in Dellaporta et al. (1983). RT-PCR Assay; The cDNAs were generated by sense primer 
5'TTCATGGAAAGACAGGGGCAA 3' and antisense primer 5'AAGTCTACAGGCTATTTATTATAAGTCTAA3' which were described before by Menzel et al. (2002), to obtain $677 \mathrm{bp}$ fragment related to the partial CP for screening of ACLSV isolates. cDNAs were obtained from ACLSV NAs with Thermo Science Verso 1 Step RT-PCR Kit package in accordance with manufacturer's manual. The amplification process and conditions were described at Menzel et al. (2002). Therefore, ACLSV thermal cycling parameters were, reverse transcription at $42{ }^{\circ} \mathrm{C}$ for $30 \mathrm{~min}$; one cycle for activation of $\mathrm{Taq}$ polymerase at $95{ }^{\circ} \mathrm{C}$ for $15 \mathrm{~min}$ chained by 34 cycles of denaturation at $94{ }^{\circ} \mathrm{C}$ for $30 \mathrm{~s}$, annealing at $62{ }^{\circ} \mathrm{C}$ for $30 \mathrm{~s}$, and extension at $72{ }^{\circ} \mathrm{C}$ for $1 \mathrm{~min}$. The final extension step was carried out at $72{ }^{\circ} \mathrm{C}$ for $7 \mathrm{~min}$.

The amplified PCR products were run in $1.5 \%$ agarose gel, stained with ethidium bromide and visualized under UV illumination.

Table 1. Results obtained from plant samples as a result of serological and molecular analyses

\begin{tabular}{c|c|c}
\hline \multirow{2}{*}{ Virus species } & \multicolumn{2}{c}{ Result and assays } \\
\cline { 2 - 3 } & ELISA & RT-PCR \\
\hline Arabis mosaic virus (ArMV) & - & - \\
\hline Strawberry latent ringspot virus (SLRSV) & - & - \\
\hline Apple stem pitting virus (ASPV & - & - \\
\hline Apple stem grooving virus (ASGV) & - & - \\
\hline Tobacco blackring virus (TBRV) & - & - \\
\hline Cherry leafroll virus (CLRV) & - & - na \\
\hline Strawberry latent ringspot virus (SLRSV) & + Strax sp. & - \\
\hline Prune dwarf virus (PDV) & - & \\
\hline Prunus necrotic ringspot virus (PNRSV) & + Strax sp. & na \\
\hline Plum pox virus (PPV) & + & + \\
\hline Apple mosaic virus (ApMV) & apple, pear, Sw. cherry, & apple, pear, Sw. cherry, \\
\hline Apple chlorotic leaf spot virus (ACLSV) & nectarine \\
\hline
\end{tabular}

-Negative (not infected); +Positive (infected); na: non assayed by RT-PCR

\section{RT-PCR products analysis}

$10 \mathrm{ul}$ of PCR item was used with gel loading buffer and analyzed on a $1.5 \%$ agarose gel containing $0.5 \mathrm{mg} / \mathrm{ml}$ of ethidium bromide (Sambrook et al., 1989). 100 bp DNA ladder (thermo) was used on each gel to analyze PCR items.

\section{Phylogenetic analysis}

The ACLSV RT-PCR products obtained according to Menzel et al. (2002) primers, were sequenced by a commercial sequencing company and dnasp5 program was conducted. Phylogeny and evolutionary analyses were made by MEGA 7 (Molecular Evolutionary Genetics Analysis) software and neighbour joining process, according to convention analysis. Occurred sequences were compared with different isolates of ACLSV originated by host and geographical locations from gen bank (NCBI, National 
Center for Biotechnology Information). Sequences from the accessions (Table 2) had been considered. Sequence alignment of the ACLSV isolates and homology between sequences were acted in accordance with to Thompson et al. (1994). The present ACLSV isolates in the study compared with those of 23 ACLSV isolates were available in the NCBI GenBank. A sequence identity matrix of the partial CP gene of the ACLSV isolates were configured using the BIOEDIT with worldwide ACLSV sequences obtained in the GenBank.

Table 2. Accession numbers, Isolate origin, hosts and name of ACLSV isolates subjected to this molecular comparisons analysis (1-5 as bold from East Mediterranean of Turkey)

\begin{tabular}{|c|c|c|c|c|c|}
\hline No & Accession No & Country & Host & Isolate name & Identity \\
\hline 1 & MK986792 & Turkey & Nectarine & ACLSV_Nectarine & 96.12 \\
\hline 2 & MK986793 & Turkey & Cherry & ACLSV_Cherry & 96.61 \\
\hline 3 & MK986794 & Turkey & Pear & ACLSV_Pear & 96.92 \\
\hline 4 & MK986795 & Turkey & Apple & ACLSV_Apple & 97.09 \\
\hline 5 & MK986796 & Turkey & Strax officinalis & ACLSV_Strax officinalis & 96.77 \\
\hline 6 & AM498050.1 & India:Solan & Peach & & 97.42 \\
\hline 7 & GQ334201.1 & Canada & Pear & Pyrus0167 & 92.89 \\
\hline 8 & AJ586630.1 & Italya & Apricot & Apr 20 & 91.92 \\
\hline 9 & KU749434.1 & Afghanistan & $\begin{array}{l}\text { European Plum cv. Alu } \\
\text { Bokhara Shalili }\end{array}$ & $364 / 10$ & \\
\hline 10 & JQ866622.1 & Ukraine & Pear & ACLSV-43 & 85.58 \\
\hline 11 & LC475152.1 & South Korea & Pyrus Pyrifolia & ACLSV_WH & 89.09 \\
\hline 12 & AM498048.1 & India:Kullu & Wild Apricot (Chuli) & & 86.01 \\
\hline 13 & GQ334210.1 & China & Pear & SMJ & 85.44 \\
\hline 14 & AJ586634.1 & Spain & Apricot & Apr 62 & \\
\hline 15 & X99752.1 & & Cherry & Balaton1 & \\
\hline 16 & AJ586644.1 & Italy & Peach & PE-FC & \\
\hline 17 & MF069041.1_ & Czech Republic & Cherry & Lambert 43 & \\
\hline 18 & AY730560.1 & Turkey & Sweet Cherry & ASwC43 & 83.19 \\
\hline 19 & AJ586654.1 & Jordan & Plum & PL111 & 91.92 \\
\hline 20 & AJ586653.1 & Italy & Plum & PL110 & 80.22 \\
\hline 21 & JN849004.1 & China & & $\mathrm{Y} 2$ & 69.83 \\
\hline 22 & EU223295.1 & USA & & & 70.27 \\
\hline 23 & JN848998.1 & China & & $\mathrm{Z} 2$ & 71.46 \\
\hline 24 & GQ334195.1 & Canada & Apple & Malus0582 & 93.70 \\
\hline 25 & FJ952176.1 & Belgium & Apple & $5 \mathrm{Be}$ & 90.21 \\
\hline 26 & FJ952177.1 & Serbia & Apple Cultivar Granny S. & $11 \mathrm{Sr}$ & 90.38 \\
\hline 27 & DQ329162.1 & Bulgaria & Apple & P10R1D3 & 86.24 \\
\hline 28 & KC244768.1 & Belarus & Malus X Domestica & Sakavita-1 & 86.22 \\
\hline
\end{tabular}

\section{Recombination event analysis}

The Recombination Detection Program v4.16 (RDP4) was performed (Martin et al., 2010), by utilizing the RDP, GENECONV, Chimaera, MaxChi, BOOTSCAN, SISCAN and 3SEQ methods implemented in the RDP 4 program with default settings. These 
recombination determinations have been accepted if determined as "clear" recombination by more than four methods with a p-value > 1×10-6 (Martin and Rybicki, 2000).

\section{Genetic diversity analysis for ACLSV population of EMR}

The estimate of nucleotide diversity values of EMR ACLSV isolates is structured by DNASP version 5.0 (Librado and Rozas, 2009).

The Pi value, including nucleotide diversity, was estimated by Tajima, [1983), with the average number of nucleotide differences between two random sequences in a population.

The frequency and number of haplotypes in a population of haplotype diversity $(\mathrm{Hd})$ was conducted by Watterson (1975) according to the $\theta$ Estimator from the number of segregated sites (S), while the average ratio of non-synonymous and synonym substitutes (Tajima's d'si) was conducted by Tajima (1989), and the D and F analyses of $\mathrm{Fu}$ and $\mathrm{Li}$ were conducted by $\mathrm{Fu}$ and $\mathrm{Li}$ (1993) neutrality tests.

\section{Results and discussion}

\section{Serology (DAS-ELISA)}

Commercially available ELISA kits have been used to serologically detect virus diseases that are harmful in stone fruit trees. ACLSV, ApMV, PPV, PNRSV, PDV and other important temperate zone fruit viruses (Table 1) commercially available kits have been used in accordance with the procedures reported by the companies. As a result of the ELISA tests, mostly non-mixed infections were determined from samples collected from important temperate climate fruits such as quince, pear, apple, cherry, apricot, cherry peach and nectarine. Only one example showed multiple mixed infections. The number of viral infections detected is summarized in Table 1 according to fruit species. Accordingly, it was also tested for verification of previous serological studies, one Nectarine isolate of ACLSV was collected from Yenice/Adana (2019) and one Apple isolate from Fındıkl1/Adana (2011), one Pear isolate from Kamışl1/Adana (2006), one Sweet cherry isolate from Çamard1/Nigde (2013) and one Strax officinalis isolate supplied from Kayseri (by Dr. H. Fidan; 2018) in the samples, ACLSV infection was confirmed by giving at least twice the healthy control value and a higher reading value. Only Strax officinalis has been identified with a triple mixed viral infection. This mixed infection was found to be caused by ACLSV, PDV and ApMV.

In contrast to having positive results against to ACLSV, ApMV and PDV, ELISA did not give positive results for all samples for the rest of among all 12 tested different viruses (Table 1).

However, serological techniques, although very widely used costs are high, each phenological period of plants and different organs of the delicate results can not stand as techniques. For these reasons, molecular techniques are applied to verify the results. In particular, low costs, high sensitivity and detailed characterization possibilities can be provided in part, as well as an easy-to-implement technique can be considered as an advantage.

\section{RT-PCR, sequence analysis and phylogenetic analysis}

In addition, reverse transcription-polymerase chain reaction (RT-PCR) method was used to obtain the complementary DNA (cDNA) from the RNAs obtained as a result of 
Total RNA isolation. In the next stage, approximately 677 bp-sized compounds containing conserved regions associated with the ACLSV CP gene parts by means of forward and reverse primers were observed in $1.5 \%$ agarose gel containing $0.5 \mathrm{mg} / \mathrm{ml}$ of ethidium bromide (Fig. 2).

DAS-ELISA positive results of isolates obtained from different production areas of the Eastern Mediterranean region were confirmed in this way. Phylogenetic tree was created based on sequence analyses of amplicons or RT-PCR products obtained.

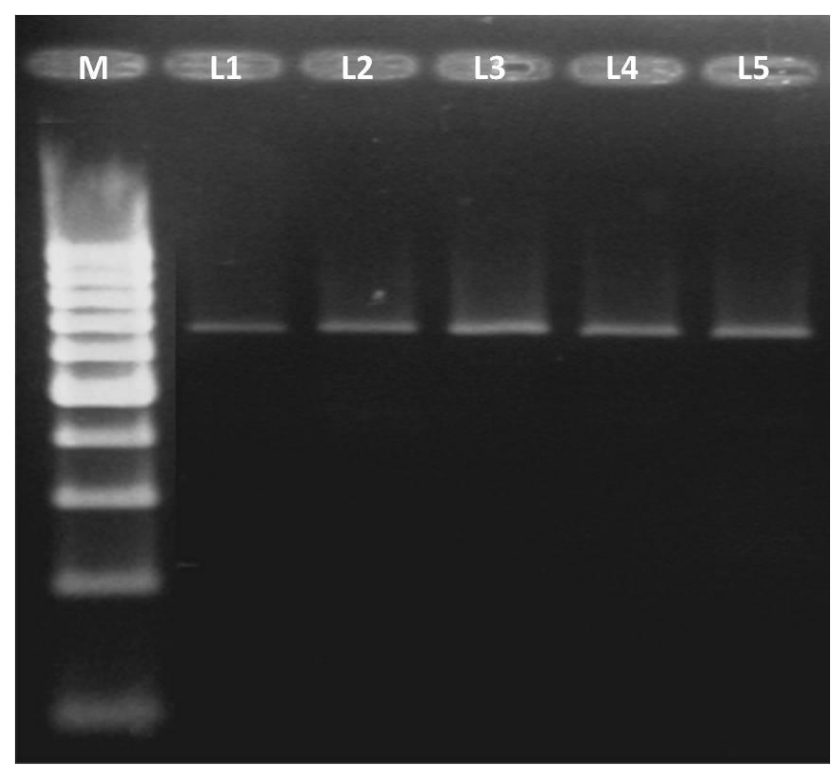

Figure 2. First lane M DNA ladder; RT-PCR products of $677 \mathrm{bp}$ of ACLSV CP on agarose gel (1.5\%) (Lane1 nectarine isolate of ACLSV; Lane2 apple isolate; Lane3 pear isolate; Lane4

Strax officinalis isolate; Lane5 sweet cherry isolate from Mediterranean Cost in Turkey

\section{Phylogenetic analysis}

Designated sequences have been compared with different isolates' sequences of ACLSV from the accessions (Table 2). Phylogeny was conducted by Mega7, as indicated by entered ACLSV sequences (Fig. 3). The evolutionary history was inferred using the Neighbor-Joining method. The optimal tree with the sum of branch length $=22,06180530$ is shown. The percentage of replicate trees in which the associated taxa clustered together in the bootstrap test (1000 replicates) are shown next to the branches.

The Phylogenetic tree is drawn to scale, with branch lengths in the same units as those of the evolutionary distances used to infer the phylogenetic tree. The computed evolutionary distances using the Maximum Composite Likelihood method, are in the units of the number of base substitutions per site. The analysis had been involved 28 nucleotide sequences. All positions containing gaps and missing data were eliminated. There were a total of 237 positions in the final dataset. Evolutionary analyses were conducted in MEGA7. The Stone Ansd Pome Fruit Samples from East Mediterranean of Turkey in Genbank with accession Number (Table 2) MK986792 Nectarine, MK986793 Cherry, MK986794 Pear, MK986795 Apple and MK986796 Strax officinalis were accessed as to NCBI system (Fig. 3) and listed below with other isolates from worldwide in Table 2 and matrixed in Table 3. 


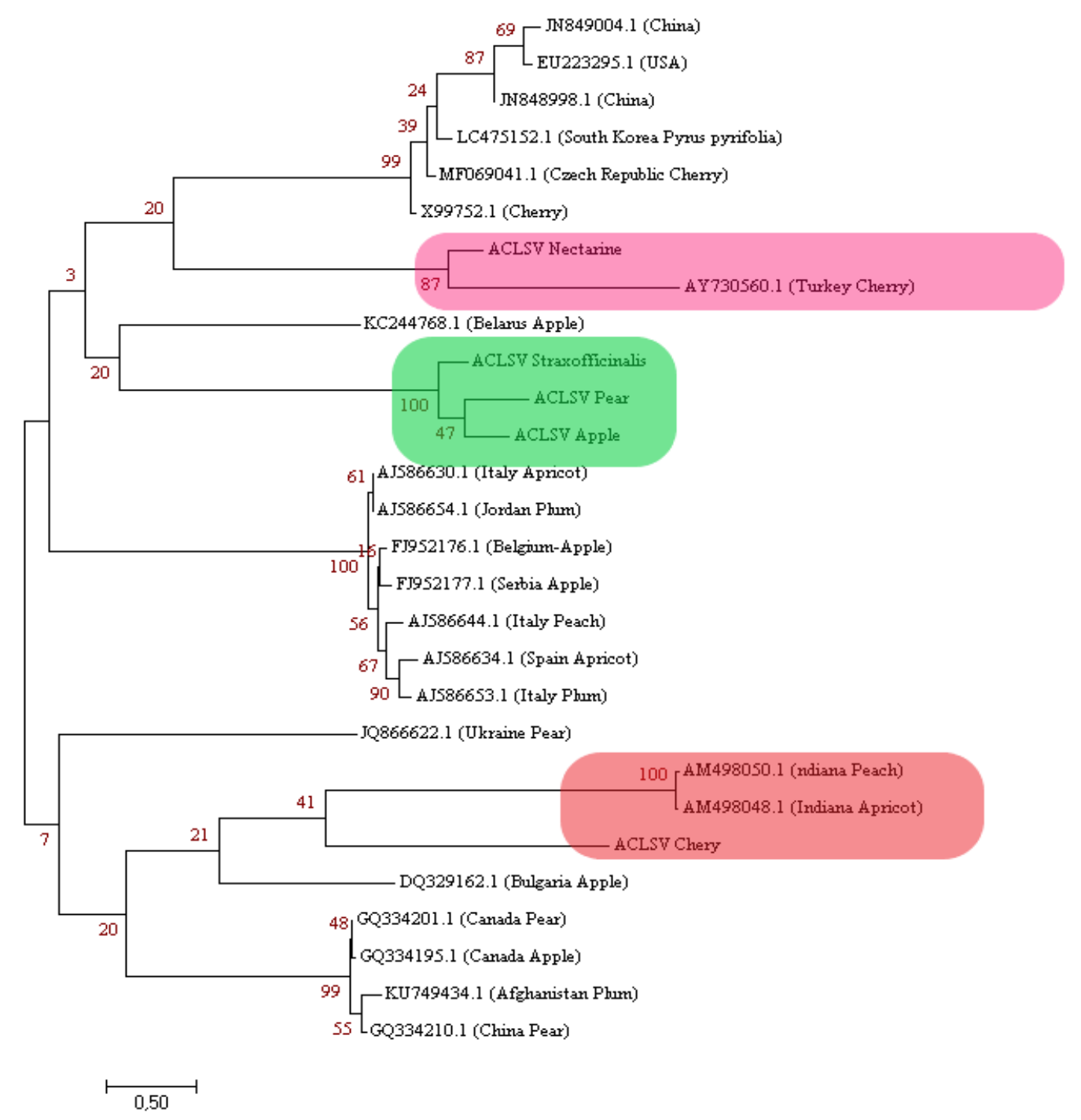

Figure 3. Phylogenetic tree of five different ACLSV isolates from Mediterranean coast of Turkey and 23 of gene bank, were clustered within the GenBank database

Despite of having approximately $97.09 \%$ similarity with each other isolates from Turkey there are three clades among Stone and Pome Fruit isolates from East Mediterranean Turkey (EMT). It may be caused by material origin. The sequences were clarified with Accession Num. MK986792 Nectarine isolates (96.12\%) from EMT have similar homology with Accession Num. AY730560.1 Sweet Cherry isolate (83.19\%) from Turkey (in pink cloud at tree). While Accession Num. MK986794 Pear (96.92\%), Accession Num. MK986795 Apple (97.09\%) and Accession Num. MK986796 Strax officinalis (96.77\%) from EMT were in cluster with Accession Num. KC244768.1 Malus X Domestica from Belarus isolate (86.22\%) (in green cloud at tree).

The third cluster which is covering Accession Num. MK986793 ACLSV Cherry (96.61\%) (in coral orange cloud at tree) has two more isolates, with Accession Num. AM498048.1 Wild Apricot (Chuli) (86.01\%) from India: Kullu and Accession Num. AM498050.1 Peach from India: Solan (97.42\%). This cluster next to other branch, has Accession Num. DQ329162.1 Apple isolates (86.24\%) from Bulgaria (Tables 2 and 3; Fig. 3). 
Table 3. Pairwise distances have matrixed according to the accession numbers (also in Table 2), of ACLSV isolates which are MK986792 Nectarine, MK986793 Cherry, MK986794 Pear, MK986795 Apple and MK986796 Strax officinalis in this study for molecular comparisons analysis (1-5) from EMT. It compares the degree of proximity between red and blue
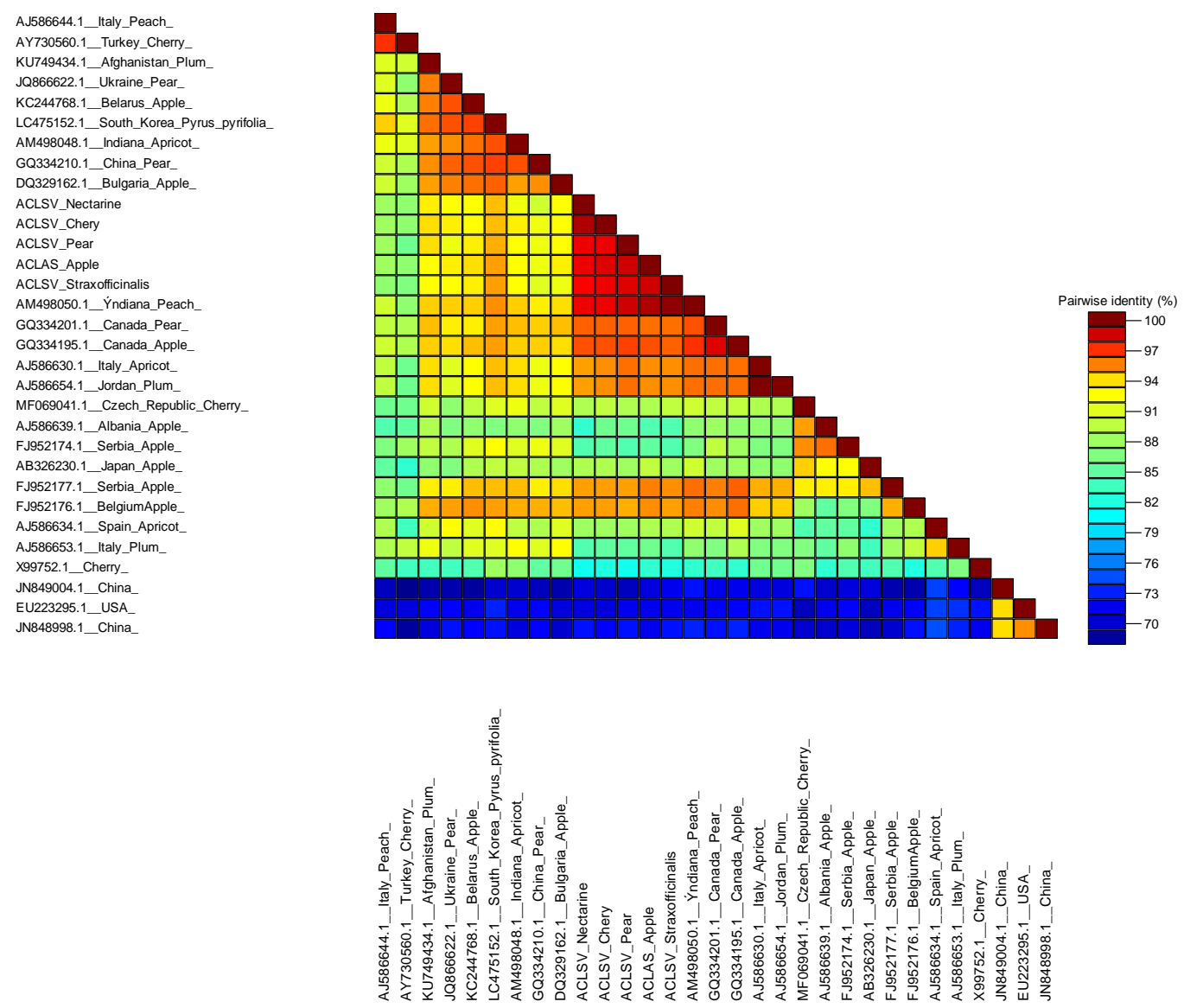

Dark Red indicates the closest kinship level. While Dark Blue is the opposite

According to Liu et al. (2014) specifications, isolates P205, B6 and Ta Tao 5 can be determined based on some amino acid points on the Capsid protein. According to this analysis, ACLSV-Pear, ACLSV-Nectarine, ACLSV-Apple, ACLSV-Cherry, ACLSVStrax officinalis isolates from Turkey all have amino acid alignment within the B6 group isolates (Table 4). In our result CP based classification for ACLSV was proposed likely on the covariation analysis of the five amino acids at positions 40, 59, 75, 130 and 184, which are highly conserved within two clusters recently described by Yaegashi et al. [2007). The Amino acid clusters of East Mediterranean ACLSV isolates were designated as 'B6 type' due to the isolates containing Ser40, Leu59, Tyr75, Ala86, Thr130 and Leu184 series.

Table 4. Protein-based amino acid sequence of ACLSV isolates

\begin{tabular}{c|c|c|c|c|c|c} 
Group name & $\mathbf{4 0}$ & $\mathbf{5 9}$ & $\mathbf{7 5}$ & $\mathbf{8 6}$ & $\mathbf{1 3 0}$ & $\mathbf{1 8 4}$ \\
\hline Group I P205 & Ala & Val & Phe & Ile & Ser & Met \\
Group II B6 & Ser & Leu & Tyr & Ala & Thr & Leu \\
Group III Ta Tao 5 & Ser & Val & Tyr & Leu & Lys & Ile
\end{tabular}


MK986794 >ACLSV_Pear (B6 type) nucleotide and amino acid sequence

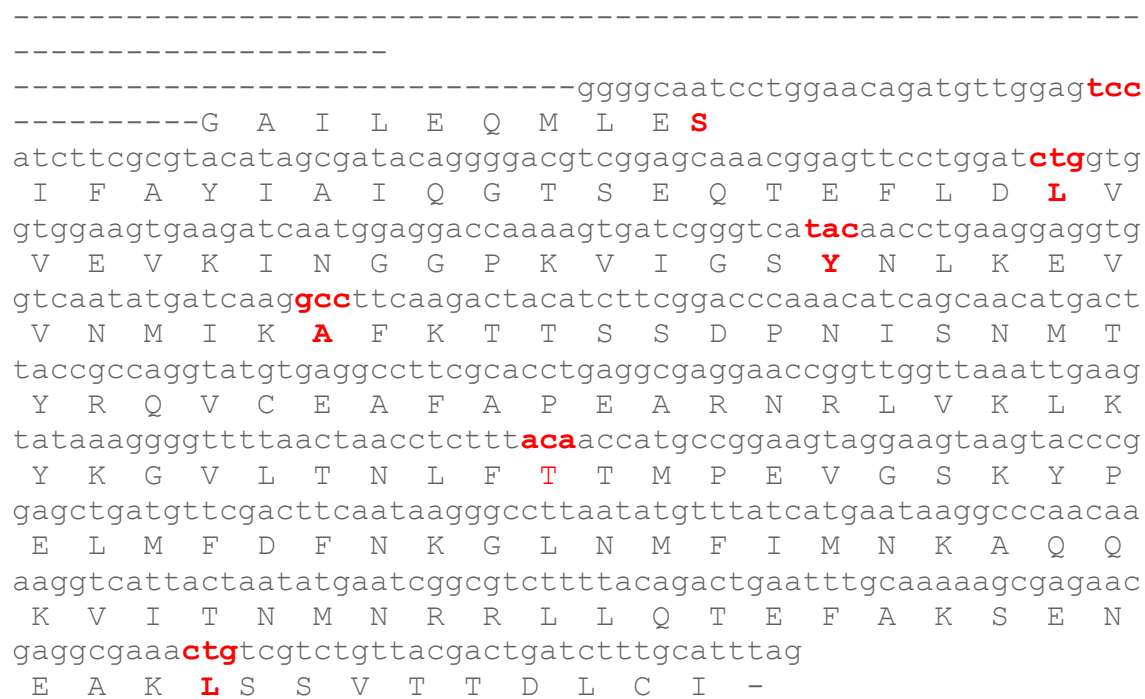

MK986795>ACLSV_Apple (B6 type) nucleotide and amino acid sequence

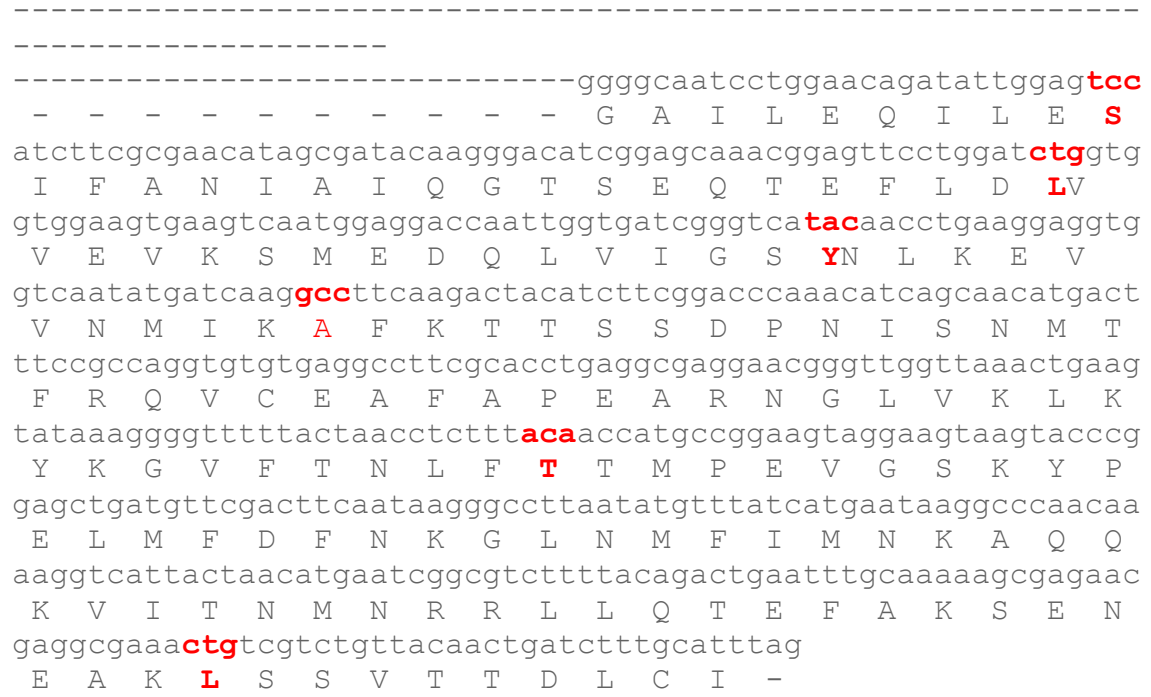

MK986796>ACLSV_Strax_officinalis (B6 type) nucleotide and amino acid sequence

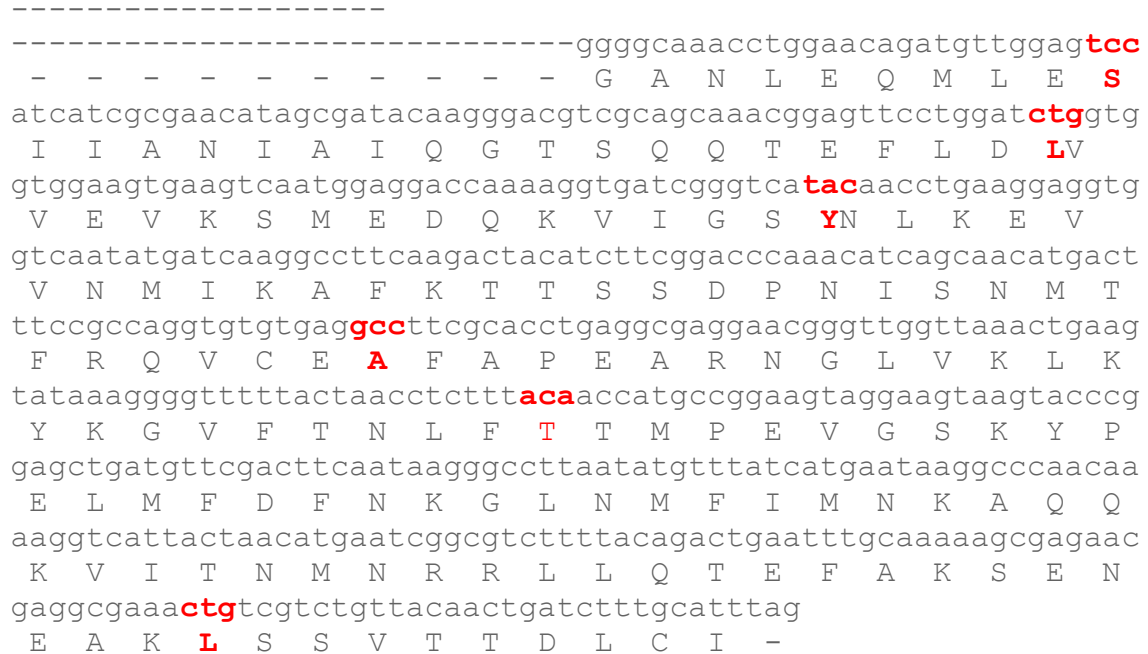

APPLIED ECOLOGY AND ENVIRONMENTAL RESEARCH 18(1):141-157.

http://www.aloki.hu • ISSN 15891623 (Print) • ISSN 17850037 (Online)

DOI: http://dx.doi.org/10.15666/aeer/1801_141157

(c) 2020, ALÖKI Kft., Budapest, Hungary 
MK986792>ACLSV_Nectarine (B6 type) nucleotide and amino acid sequence

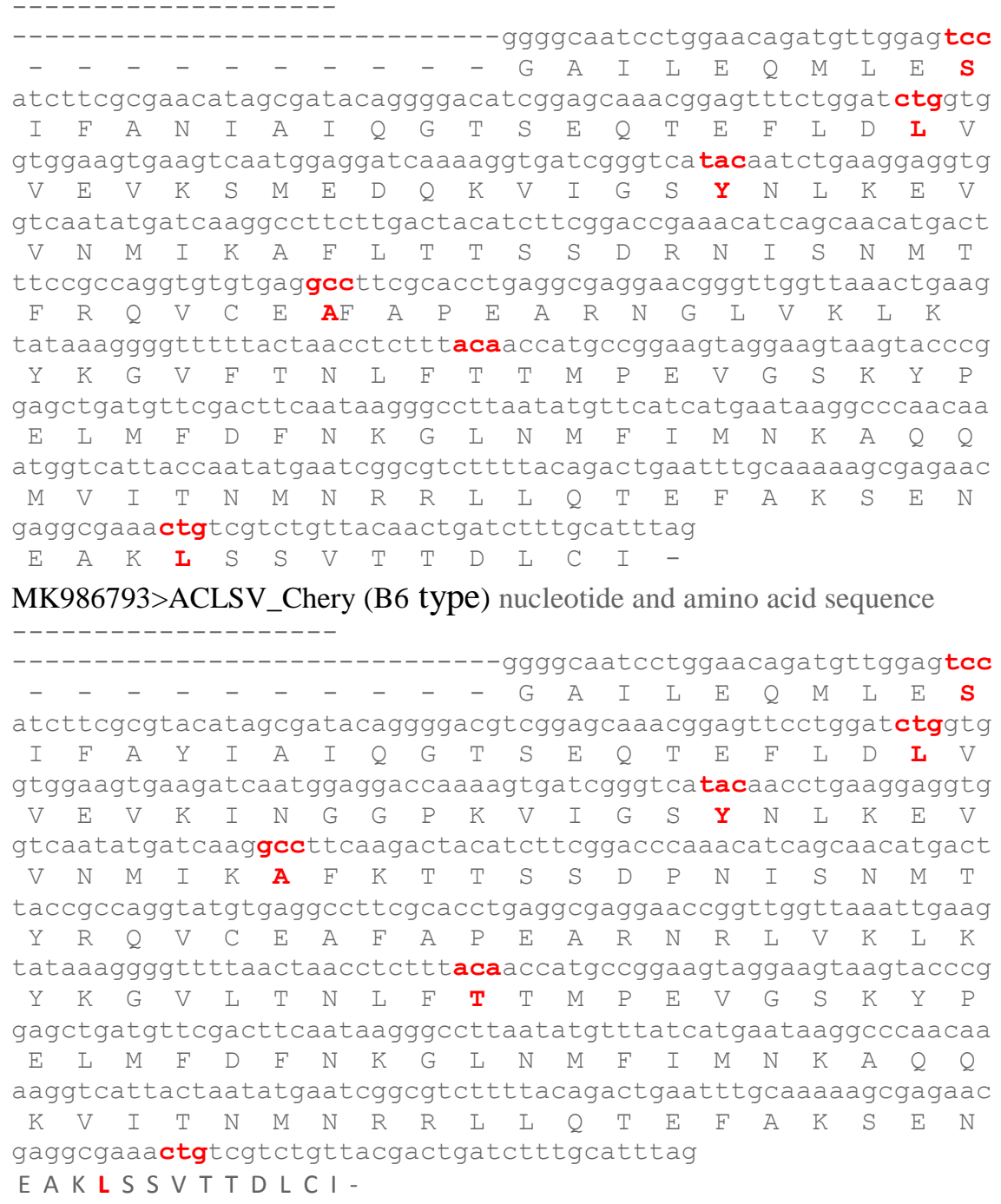

\section{Recombination analysis by RPD4}

In order to determine recombination events with each other of the 5 isolates used in the phylogenetic tree, "the Recombination Detection Program v4.16 RDP4" was used. RPD 4 (Martin et al., 2010) according to the program given 7 algorithms; recombination events were analyzed.

The presence of recombination signal on ACSLV_Pear isolate was determined according to BootScan and SisCan algorithms from 7 algorithms used. When the RDP4 program data was examined, the ACSLV_pear isolate was determined to be a potential recombinant (Table 5). Because the nucleotide variation value $(\mathrm{p}>0.1)$ was determined in two algorithms.

In analyses performed using RDP4, recombinations must be determined by at least three of the methods in the program (Martin and Rybicki, 2000; Martin et al., 2010). However, in this study the discovery of recombination signals in only two algorithms established the general belief that recombination events were not detected in the 5 isolates in the study (Table 5; Figs 4 and 5). 


$$
-152-
$$

Table 5. CP genes based "The Recombination Detection Program" v4.16 algorithms (BootScan and SiScan) of the ACLSV Pear isolate

\begin{tabular}{c|c|c|c}
\hline Methods & Time elapsed & Unique events (Rec. signals) & Av. P. Val \\
\hline RDP & $0,00 \mathrm{~s}$ & $0(0)$ & -- \\
GENECONV & $0,00 \mathrm{~s}$ & $0(0)$ & -- \\
BootScan & $0,12 \mathrm{~s}$ & $1(0)$ & $1,126 \times 1002$ \\
MaxChi & $0,00 \mathrm{~s}$ & $0(0)$ & -- \\
Chimera & $0,20 \mathrm{~s}$ & $0(0)$ & -- \\
SisCan & $0,00 \mathrm{~s}$ & $1(0)$ & $1,591 \times 1003$ \\
3Seq & $0,00 \mathrm{~s}$ & $0(0)$ & -- \\
TOTAL & $0,41 \mathrm{~s}$ & $1(2)$ & \\
\hline
\end{tabular}

Rec. Signal ACLSV-Pear/Major Parent:ACLSV Apple/Minor Parent unknown

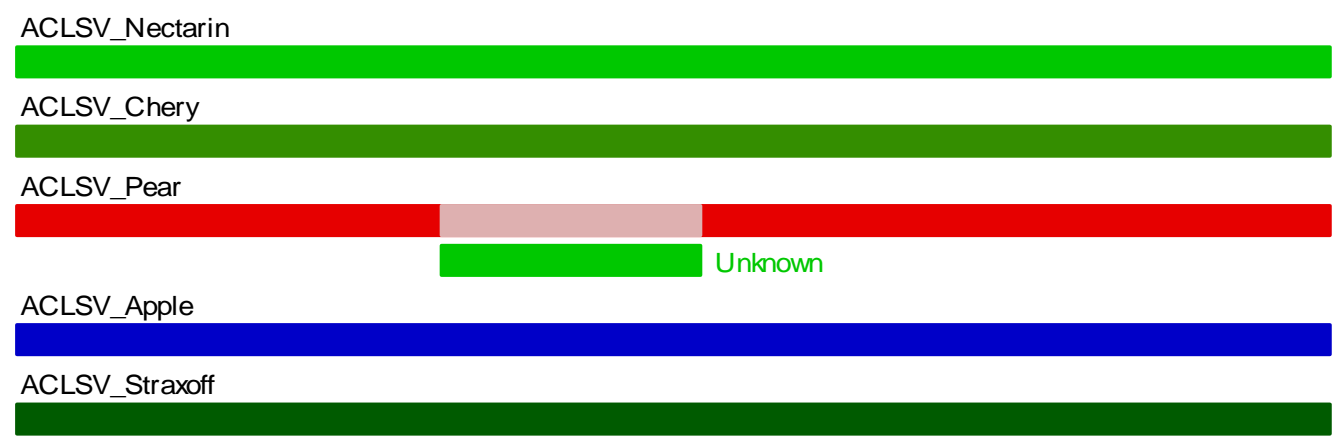

Figure 4. SISCan Model analyses were identified possible recombination sites within the fragment of ACLSV movement protein gene sequences at approximately positions 75 and 86, respectively only for ACLSV pear isolates

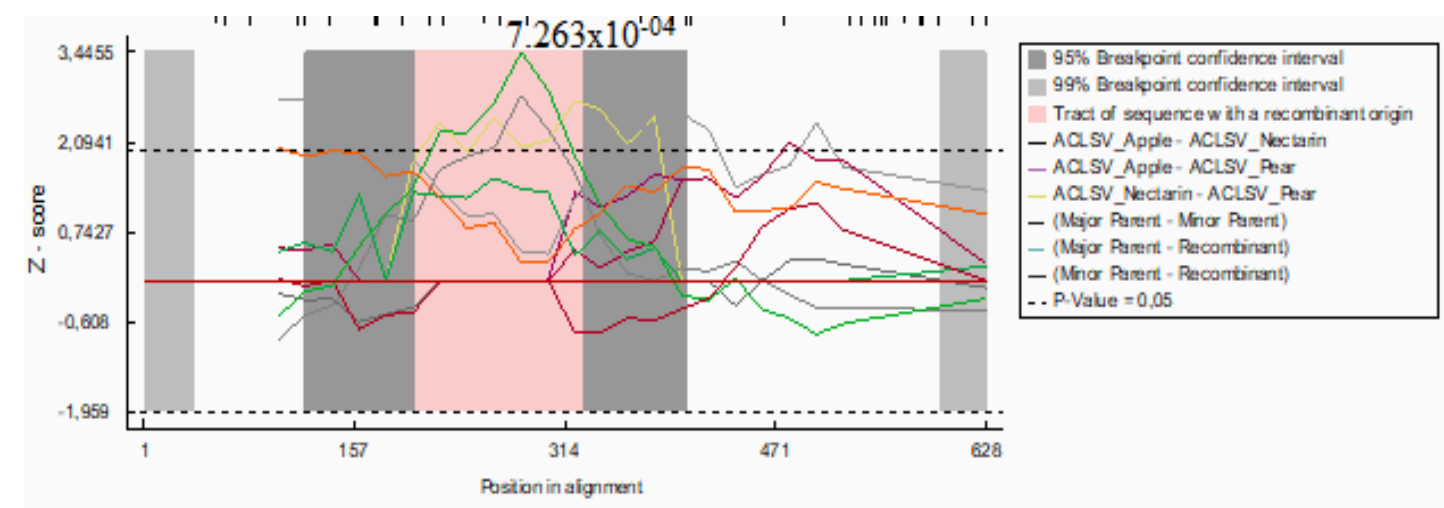

Figure 5. BootSCAN Model analyses identified possible recombination sites within the fragment of ACLSV movement protein gene sequences at positions 75 and 86, respectively only for ACLSV pear isolates

\section{Population diversity data according to DNASp6}

ACSLV isolates obtained from different regions were subjected to recombination analysis using the DNSp6 program. According to this analysis, S:41 fields were 
identified in Segregession (polymorphic). According to Hudson (1987) data, recombination parameters have been estimated. The distribution variance of the samples was determined as $\mathrm{Kij}, \mathrm{Sk}^{\wedge} 2: 72,838$. Theta estimate data for each gene: 18,800, functional data $\mathrm{g}(\mathrm{C}, \mathrm{n}) 0.1798$, estimated value of $\mathrm{R}$ for each gene: 368 was determined.

The number of minimum recombination events was determined according to Hudsan and Kaplan (1985). According to this analysis, the number of binary comparisons analyzed was determined as 820 . The number of minimum recombination activity was found to be at $(54.61)(61,407)$ points as Rm:2 (Table 6).

Table 6. Population diversity data according to DNASp6 of the ACLSV pear isolate

\begin{tabular}{c|c|c|c|c|c|c|c|c|c|c}
\hline Region & \multicolumn{7}{c|}{ Population statics } & \multicolumn{2}{c}{ Tests of neutrality } \\
\hline \multirow{2}{*}{ CP } & n & S & Hd & Pi: & dS & dN & dN/dS & Tajima's D & Fu \& Li's D & Fu \& Li's F \\
\cline { 2 - 10 } & 5 & 41 & 1.000 & 0.03072 & 0.59633 & -0.17175 & $\mathbf{0 . 2 8 8}$ & -0.6543 & -0.3364 & -0.3364 \\
\hline
\end{tabular}

n: Number of sequences; S: number of segregating sites; Hd: haplotype diversity; Pi: Nucleotid diversity; dS: rate of synonymous substitutions per site; dN: rate of non-synonymous substitutions per site

\section{Conclusion}

The East Mediterranean region is a unique area for many varieties of plants grown in Turkey. The viruses similarly with the other plant diseases can restrict the production via reducing fruitfulness all through the Mediterranean region of Turkey. But in practice, there is no chemical suggestion to control virus diseases unlike the others. Consequently, their epidemiology and molecular bases have to be well decoded to apply control measures. Additionally, resistant cultivars and sanitation should be used for controlling the many viruses in practices.

Natural distribution and occurrence of Temperate Zone viruses in the studied area have determined in Turkey. Our results showed as it has already mentioned above that sanitary situations in stone and pome fruits growing regions are very vitally important in Turkey.

Therefore, molecular epidemiology of ACLSV should be well understood for the prevention. The insufficient of ecologically more important agrochemical disease management strategy, has been increased the jeopardy of infection spread. As well, it can also originate progressively from different annual species and occurs after infection with infected saplings or contamination sources (herbaceous and woody plants) if the insufficient level is suppressed. This is the first preliminarily recombination event report of ACLSV pear isolate among the other isolates from different hosts in the Mediterranean region of Turkey. Our results have shown that reliable laboratory molecular methods with immunological ELISA and molecular RT-PCR analyses have to be used. Further advanced statistical techniques such as RPD4 etc. could be used to confirm our results and other possible recombination events. Because the new recombinant isolates, may become economically dangerous in time, it can cause aggressive breeds to form. Likewise, Fidan (2016) has reported new TSWV isolates that break down the durability of peppers.

Presumably it may more easy transmitted by infected material and cuttings. In response to this "Certified plant materials, destruction of the source of disease and prevention of vectors" are powerful strategies to overcome the disease. Recognition of new strains or isolates will help sustain disease management on the right track. Genetic 
changes due to recombination events can be very important for RNA viruses. Isolate due to point mutations in virus structures are changing so that the emergence of new isolates is realized (Fidan and Sari, 2019). Cultural methods used for preventing virus infections are not enough. Virus vectors and host weeds need to be managed.

Durable/tolerant as possible varieties should be preferred (Öztürk Keleş and Baloğlu, 2019). It is possible that the new isolates may cause severe virus diseases even in mixed or different isolates in the host plants. It is not possible to predict this without observing or experiencing the negative effects and epidemiology of recombinants in agricultural ecology and natural ecology (Fidan et al., 2019).

This paper might additionally indicate that broaded distribution of infected host species between countries and regions will allow the spread of plant's viruses. In the present paper RT-PCR was used as a standardized method for reliable detection of local ACLSV isolates. The analyses performed in this study revealed the variability between ACLSV pear and other isolates in the Eastern Mediterranean region. Molecular variability analysis of 5 ACLSV isolates in the Eastern Mediterranean region, were detected comparable. The phylogenetic tree separated the 5 ACLSV isolates into only 3 subgroups (but not the main group). In addition, our results highlighted possible relationships between ACLSV clusters and host resources. Viruses with large host sequences such as ACLSV are highly likely to undergo recombination.

In addition, isolates resulting from mutation and recombination with high adaptation or adaptability will be able to reach a wider host sequence. This may have severe ecological consequences. In order to detect and identify measures, race and isolate variations should be better analyzed with detailed research. Vertical transmission of ACLSV and many viral agents among different plant species may be the result of recombination or mutation delivery.

Variation analysis will be better understood over time as more advanced technologies emerge and the analysis width of these methods increases. Applicable and facilitated algorithms will be able to reveal wider host sequences and variations in geographic area. Thus, threat risks on agricultural and environmental ecologies will have the potential to be proactively resolved. Moreover, full and true decoding of recombination may open new accessions to the management against ACLSV and others. Deep impacts on the ecological environment can be prevented by well understanding of virus relationships. As well, the detailed and multidisciplinary projects should be acted. All isolates in the study were eradicated on behalf of the country's interests.

Acknowledgements. Thanks to Prof. M. Asil YILMAZ for critical review of the publication.

Conflict of interests. The authors declare that they have no conflict of interests.

Ethical approval. This article does not contain any studies with human participants or animals performed by any of the authors.

\section{REFERENCES}

[1] Barba, M., Clark, M. F. (1986): Detection of strains of apple chlorotic leafspot virus by F(ab)2-based indirect ELISA. - Arch. Phytophathol. Pflanzenschutz 22: 279-282.

[2] Brunt, H. A., Crabtree, K., Dallawitz, M. J., Gibbs, A. J., Watson, L. (1996): Viruses of Plants. - CAB International, Cambridge, UK. 
[3] Cağlayan, Y. K., Çalı, S. (1994): Occurrence and detection of virus and virus like diseases of plum and apricot trees in the East Mediterranean. - Proc. of 9th Cong. of the Mediter. Phytopath. Union. Sept. 18-24, Kuşadas1-Aydın, Türkiye, pp. 551-553.

[4] Candresse, T., Lanneau, M., Revers, F., Grasseau, N., Macquaire, G., German, S., Malinowski, T., Dunez. J. (1995): An immuno-capture PCR assay adapted to the detection and the analysis of the molecular variability of the Apple chlorotic leaf spot virus. - Acta Horticult. 386: 136-147.

[5] Chairez, R., Lister, R. M., (1973): A comparison of two strains of apple chlorotic leaf spot virus. - Phytopathology 63: 1458-1464.

[6] Clark, M., Adams, A. M. (1977): Characteristics of miooplate method of enzymelinked immunosorbent assay for the detection of plant viruses. - J. Gen. Virol. 34: 475-483.

[7] Değirmenci, K., Akbaş, B. (2013): Molecular detection of apple chlorotic leaf spot virus in different host in the Central Anatolia Integrated protection of fruit crops. - IOBCWPRS Bulletin 91: 337-343.

[8] Dellaporta, S. L., Wood, J., Hicks, J. B. (1983): A plant DNA mini-preparation: version 2. - Plant Mol Biol Rep. 1(4): 19-21. DOI: 10.1007.

[9] Desvignes, J. C., Boye, R. (1989): Different diseases caused by chlorotic leaf spot virus on the fruit trees. - Acta Hort. 235: 31-38.

[10] Dosba, F., Lansac, M., Pêcheur, G., Teyssier, B., Piquemal, J. P., Michel, M., (1986): Plum pox virus detection by ELISA technique in peach and apricot infected trees at different growing stage. - Acta Horticulturae 193: 187-191.

[11] Dunez, J. (1986): Preliminary observations on virus and virus like diseases of stone fruit trees in Mediterranean and Near East countries. - FAO Plant Protection Bulletin 34: 4348.

[12] Dunez, J., Delbos, R. (1988): Closteroviruses. - In: Smith, I. M., Dunez, J., Lelliot, R. A., Phillips, D. A., Archer, S. A. (eds.) European Handbook of Plant Diseases. Blackwell, Oxford, pp. 5-7.

[13] Elibüyük, İ. Ö. (1998): Malatya ilinde yetiştirilen sert çekirdekli meyve ağaçlarındaki viruslerin tanımlanması üzerinde araştırmalar. - Doktora tezi, Ankara Üniversitesi, Fen Bilimleri Enstitüsü.

[14] Fidan, H. (2016): Antalya'da Örtü Altı Domates ve Biber Alanlarında Dayanıklılık Kıran Tomato spotted wilt virus (TSWV) İzolatların Genetik Kıyaslanması. - VI. Türkiye Bitki Koruma Kongresi KONYA, Türkiye, pp. 560-560.

[15] Fidan, Ü., Özdemir, S. (1998): Kiraz ağaçlarında görülen virüslerin DAS-ELISA ile belirlenmesi. - Zirai Mücadele Araştırma Enstitüsü, Bornova/İzmir. www.tagem.gov.tr/yeni\%20web/projeler/uygulamaya\%20aktarilan/projeler00/bsad00/11. HTM.

[16] Fidan, H., Sari, N. (2019): Molecular characterization of resistance-breaking tomato spotted wilt virus (TSWV) isolate medium segment in tomato. - Applied Ecology and Environmental Research 17(2): 5321-5339.

[17] Fidan, H., Karacaoğlu, M., Koç, G., Çağlar, B. K. (2019): Tomato yellow leaf curl virus (TYLCV) strains and epidemiological role of Bemisıa tabaci (Hemiptera: Aleyrodidae) biotypes on tomato agroecology in Turkey. - Applied Ecology and Environmental Research 17(4): 9131-9144.

[18] Flegg, H. C., Clark, M. F. (1979): The detection of apple chlorotic leaf spot virus by a modified procedure of enzyme-linked immunosorbent assay (ELISA). - Annals of Applied Biology 91: 61-65.

[19] Fu, Y.-X., Li, W.-H. (1993): Statistical tests of neutrality of mutations. - Genetics 133: 693-709.

[20] German, S., Candresse, T., Lanneau, M., Huet, J. C., Pernollet, J. C. Dunez, J. (1990): Nucleotide sequence and genomic organisation of apple chlorotic leaf spot virus. Virology 179: 104-112. 
[21] Hudson, R. R. (1987): Estimating the recombination parameter of a finite population model without selection. (Reprinted). - Genetics Research 89(5-6): 427-32. DOI: 10.1017/S0016672308009610.

[22] Hudson, R. R., Kaplan, N. L. (1985): Statistical properties of the number of recombination events in the history of a sample of DNA sequences. - Genetics 111(1): 147-164.

[23] Koç, G., Baloğlu, S., (2007): Çukurova'da Sharka (PPV; Plum Pox Potyvirus). - Türkiye II. Bitki Koruma Kongresi Bildirileri.

[24] Koç, G., Bayırdar, L., Baloglu, S. (2008): Pear, a new host of Apple chlorotic leaf spot virus in Turkey. - Journal of Plant Pathology 90(2): 397-400.

[25] Kuzmitskaya, P., Titok, V., Anoshenko, B., Urbanovich, O. (2016): Molecular variability of Apple chlorotic leaf spot virus isolated in Belarus. - Environmental and Experimental Biology 14: 121-126.

[26] Librado, P., Rozas, J. (2009): DnaSP v5: a software for comprehensive analysis of DNA polymorphism data. - Bioinformatics 25: 1451-1452.

[27] Lister, R. M. (1970): Apple Chlorotic Leaf Spot Virus. - No. 30 in CMI AAB Description of Plant Viruses. CMI/AAB, Kew, UK.

[28] Liu, P., Li, Z., Song, S., Wu, Y. Y. (2014): Molecular variability of Apple chlorotic leaf spot virus in Shaanxi, China. - Phytoparasitica 42: 445-454.

[29] Martelli, G. P., Candresse, T., Namba, S. (1994): Trichovirus, a new genus of plant viruses. - Arch. Virology 134: 451-455.

[30] Martin, D., Rybicki, E. (2000): RDP: detection of recombination amongst aligned sequences. - Bioinformatics 16: 562-563.

[31] Martin, D. P., Lemey, P., Lott, M., Moulton, V., Posada, D., Lefeuvre, P. (2010): RDP3: a flexible and fast computer program for analyzing recombination. - Bioinformatics 26 : 2462-2463.

[32] Menzel, W., Jelkmann, W., Maiss, E. (2002): Detection of four apple viruses by multiplex RT-PCR assays with coamplification of plant mRNA as internal control. Journal of Virological Methods 99: 81-92.

[33] Nemeth, M. (1986): Virus, Mycoplasma and Rickettsia Diseases of Fruit Trees. Akademiai Kiado, Budapest.

[34] Niu, F. Q., Pan, S., Wu, Z. J., Jiang, D. M. Li, S. F. (2012): Complete nucleotide sequences of the genomes of two isolates of apple chlorotic leaf spot virus from peach (Prunus persica) in China. - Arch Virol 157:783-786.

[35] Öztürk, Y. (2012): Isparta Kiraz Üretim Alanlarında Görülen Önemli Virüslerin Serolojik Ve Moleküler Yöntemlerle Teşhisi Ve Kılıf Protein Gen Dizilimlerinin Belirlenmesi. - T. C. Süleyman Demirel Üniversitesi Fen Bilimleri Enstitüsü, Yüksek Lisans Tezi Bitki Koruma Ana Bilim Dalı Isparta.

[36] Öztürk Keleş, P., Baloğlu, S., (2019): Doğu Akdeniz Bölgesi’nde Açık Alanda Yetiştirilen Biberlerde Bazı Virüslerin Serolojik ve Moleküler Tanısı. - Alatarım 18(1): $1-11$.

[37] Poul, F., Dunez, J. (1988): Use of monoclonal antibodies for the detection of the apple chlorotic leaf spot virus. - Acta Hort. 235: 49-56.

[38] Sambrook, J., Fritsch, E. F., Maniatis, T. (1989): Molecular Cloning: A Laboratory Manual. 2nd Ed. - Cold Spring Harbor Laboratory, New York.

[39] Sipahioğlu, H. M., Myrta, A., Abou-Ghanem, N., Di Terlizzi, B., Savino, V. (1999): Sanitary status of stone fruit trees in East Anatolia (Turkey) with particular reference to apricot. - Bull. OEPP/EPPO 29(4): 439-442.

[40] Smith, I. M., Dunez, J., Philips, D. H., Lelliot, R. A., Archer, S. A. (1998): European Handbook of Plant Diseases. - Blackwell Scientific Publ., Oxford, UK.

[41] Tajima, F. (1983): Evolutionary relationship of DNA sequences in finite populations. Genetics 105: 437-460. 
[42] Tajima, F. (1989): Statistical method for testing the neutral mutation hypothesis by DNA polymorphism. - Genetics 123: 585-595.

[43] Thompson, J. D., Higgins, D. G., Gibson, T. J. (1994): CLUSTAL W: improving the sensitivity of progressive multiple sequence alignment through sequence weighting, position-specific gap penalties and weight matrix choice. - Nucl. Acids Res. 22: 46734680 .

[44] Ulubaş, Ç., Ertunç, F. (2004): RT-PCR Detection and Molecular Characterization of Prunus necrotic ringspot virus Isolates Occurring in Turkey. - Journal of Phytopathology 152: 498-502.

[45] Ulubas Serce, Ç., Rosner, A., (2006): Molecular typing of Turkish Apple chlorotic leaf spot virus isolates based on partial coat protein gene. - Phytopathologia Mediterranea 45: 117-125.

[46] Watterson, G. (1975): On the number of segregating sites in genetical models without recombination. - Theoretical Population Biology 7: 256-276.

[47] Yaegashi, H., Isogai, M., Tajima, H., Sano, T., Yoshikawa, N. (2007): Combinations of two amino acids (Ala40 and Phe75 or Ser40 and Tyr75) in the coat protein of apple chlorotic leaf spot virus are crucial for infectivity. - Journal of General Virology 88: 2611-2618.

[48] Yürektürk, M. (1984): Marmara Bölgesi'nde sert çekirdekli meyvelerde görülen Sharka virüs hastalığı üzerine çalışmalar. - Atatürk Bahçe Kültürleri Araştırma Enstitüsi. 